\title{
Using of GPS and Leveling Techniques for Determining the Orthometric Heights inside Mosul University
}

\author{
Sabah Hussein Ali \\ Remote Sensing Center \\ Resources Engineering Dept. \\ University of Mosul \\ University of Mosul
}

Nashwan Kamal-aldeen

Water

\begin{abstract}
It is possible to determine heights of selective locations through terrestrial means by tying these locations to the sea level. Practical heights in geodesy, known as orthometric heights are referred to the geoid, which is approximated by the mean sea level (MSL).

In the present study, A GPS and conventional leveling techniques were used to establish a network of (15) control points distributed inside Mosul University Campus, to be as a bench marks for the surveying applications which are very important and necessary for the civil engineering projects and the geophysical survey. The obtained results show that, there is an average variation between the orthometric heights measured by leveling instrument and the ellipsoidal heights measured by GPS, referred to as geoid undulation. ArcGIS9.1 software was applied in the study for the georeferencing process of the GPS measured dataset.
\end{abstract}

Keywords: GPS, orthometric height, mean sea level

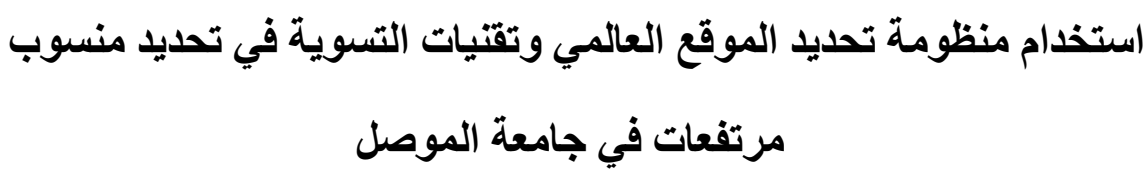

نشوان كمال الدين العمريخ

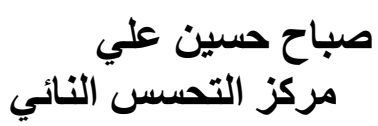




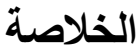

من المكن تحديد منسوب الارتفاعات لمو اقع مختارة في أي منطقة من خلال الربط بين

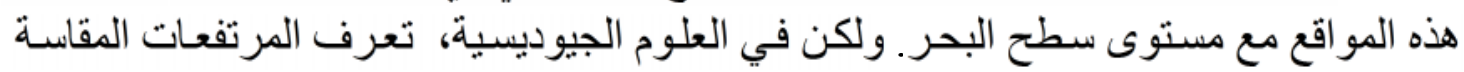

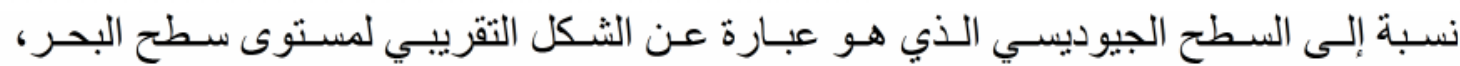

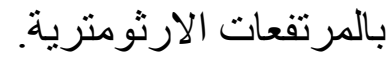

في الدر اسة الحالية، نم استخدام منظومة تحدد الموقع العالمي مع آجهزة التسوية التقليدية

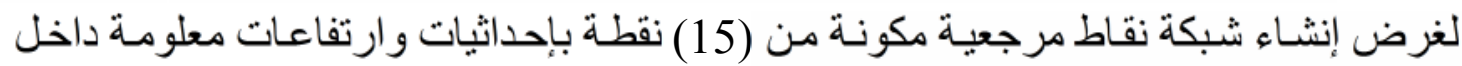

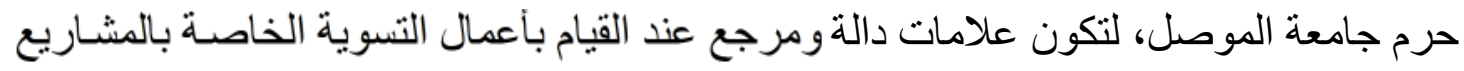

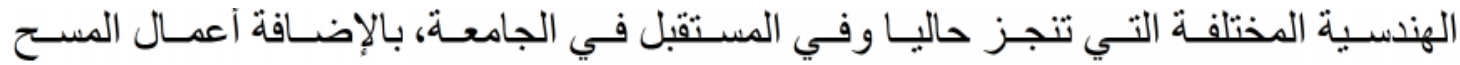
الجيوفيزيائي و الدر اسات الجيولوجية الأخرى.

أظهرت نتـائج البحث، آن معدل التغير في الارتفاعـات العموديـة (orthometric height) المقاسـة بـأجهزة التسوية والارتفاعـات الإهليجية (ellipsoidal heights) المقاسـة باستخدام

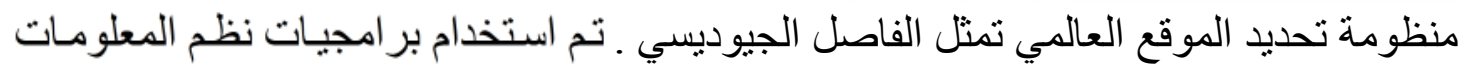

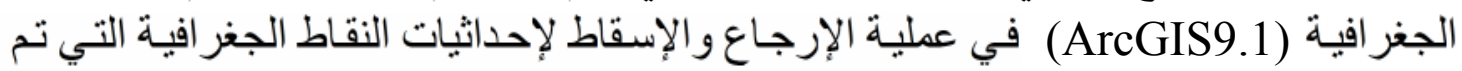
قياسها باستخدام منظومة تحديد الموقع العالمي.

\section{Received 10 June 2007 Introduction}

The expanding used of geodetic control in support of spatial information systems, demands the adoption of reliable procedures to support georeferencing of spatial data and Geographical Information System (GIS) activities. Therefore, the continuing evolution of Global Positioning System (GPS) and Geographical Information System (GIS) hardware and software as well necessitate the adoption of standards and specification in planning, surveying, methodologies, and implementation of both systems. The links between GIS software and the spatial data that given by GPS or leveling techniques develops the georeferencing process, 
and then the specifications that adopted to ensure the given level of the accuracy. A number of factors have led to an increasing need to georeferencing and to base spatial data products on a common reference frame that extends across the whole globe. These factors include growing reliance on satellite positioning systems and development of satellite based mapping systems affording increasingly higher resolution [1].

In order to produce or update spatial data related to surveying applications, a network of control points is necessary. Such a network consists of a number of points spread across the area under consideration. By referencing spatial data to such network, the resulting data and information from multiple local surveying activities can be accurately connected.

Mosul University campus lacks from necessary bench marks of a known geographical coordinates and elevation which are very important for the surveying applications.

The aim of the present research is to establish a network of control points distributed inside the campus of Mosul University. These points can be used a bench marks for the surveying applications which are very important and necessary for the civil engineering workshop and for the training courses that have been adopted in the related scientific colleges of the Mosul University. These bench marks are also important in the geological application, for the purpose of data reductions to produce the Bouguer anomaly map $[2,3]$.

A GPS and conventional leveling techniques were used to establish a network of (15) control points distributed inside Mosul University Campus. The orthometric height of the main control point(basic benchmark) for the reduction process of the other points, was calculated by using the value of the height that directly derived from GPS measurements (which are referred to the ellipsoid defined by World Geodetic System 1984 (WGS84)) and the geoidal undulation value that determined by the Earth Gravitational Model 1996 (EGM96).

The georeferencing process of the obtained spatial data in this research was achieved by using one of the recent GIS software (ArcGIS9.1). Georeferencing process is fundamental in data sharing and in integration of spatial data from various sources into a single consistent 
data set. This is often achieved using a single common geodetic reference ellipsoid, or datum [4].

\section{Ellipsoidal and Orthometric Heights}

The impact of the GPS is undeniable. In the span of just a few years GPS has became the leading positioning technology. This revolution has not been confined to surveying community, but has extended into mapping, navigation, and GIS applications. Many of these applications require accurate vertical positioning. Generally, Coordinates determination from GPS measurements uses the known positions of satellites and the measured distance between satellites and the known points. It is commonly considered as a three-dimensional system (Latitude, Longitude, and ellipsoidal height). But, the heights obtained from GPS are typically heights above an ellipsoid model of the earth [5]. It is a geodetic height which purely geometrical quantity, and represents the length of the normal to the reference ellipsoid between the ellipsoid and the point of interest. These GPS ellipsoidal heights are not consistence with leveled heights above mean sea level (MSL), often known as orthometric height [6]. The orthometric height is defined as the length of the plumb-line (a line that is always normal to the equipotential surface of the gravity field) between the geoid and the point of interest and as such is intimately related to the gravity field of the earth [7]. Thus, the knowledge of the goeid is necessary for transforming the geodetic to orthometric heights and vice versa. The geoid and ellipsoid intersect at the geoid undulations as shown in figure (1). Undulations result from several phenomena, the most significant of which is the existence of gravitational anomalies caused by the nonhomogeneous nature of the earth.

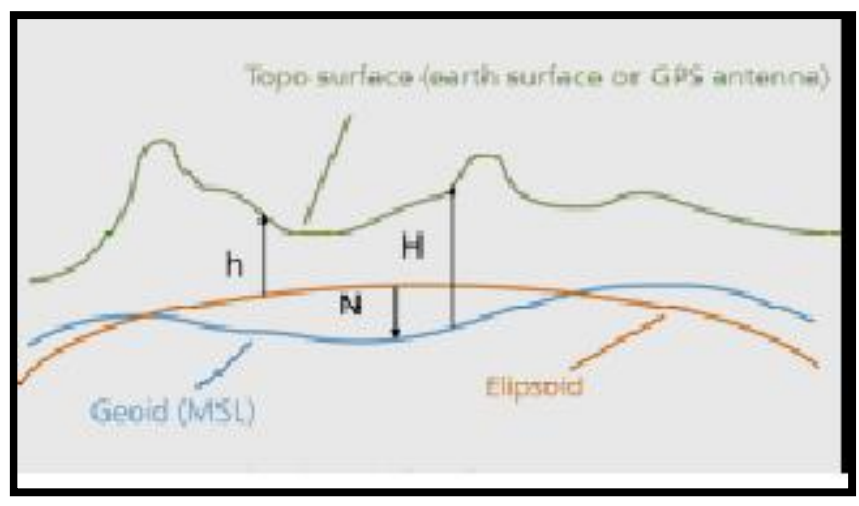


Figure (1): The relation between the earth surface, ellipsoid and geoid

The difference between GPS ellipsoid heights, $\mathrm{h}$, and leveled orthometric heights, $\mathrm{H}$, is called geoid height, N. As seen in the figure (1), the geoid height is the vertical distance from the ellipsoid to the geoid level surface. These heights obey a simple equation [1]:

$\mathrm{h}=\mathrm{H} \pm \mathrm{N}$ 1

The sign $( \pm)$ depends on the topographic variations of the study area (i.e., the relation between the orthometric and ellipsoid heights). Having such information in the form of geoid and ellipsoid heights enables geomatic engineers and other research scientist to apply this information in their respective fields thus realistically providing the opportunity for GPS to be used in GPS leveling and other application as done in the present research.

\section{GPS-Leveling Observations}

\section{EGM96 Geoid Model}

The orthometric height of the basic benchmark that has been adopted in this study was determined through the use of GPS derived dataset and the EGM96 geoid model. The EGM96 geoid model was the most recent global geopotential model that being adopted as the geopotential model for the unification of global vertical datums [1].Figure (2) shows the global map with geoid heights of the EGM96 gravity field model.

This model was developed by Goddard Space Flight Center, The National Imagery and Mapping Agency (NIMA) and the Ohio State University (OSU) to improved 360 degree spherical harmonic model representing the earth's gravitational potential. EGM96 expresses the geoid undulation values at every round arc degree $[9,10]$.

It is an optimal transformation of satellites orbit analysis, altimetry and terrestrial gravimetry into one set of spherical harmonic coefficients. It is model was used to define the geoidal undulation with respect to World Geodetic System1984 (WGS84). 


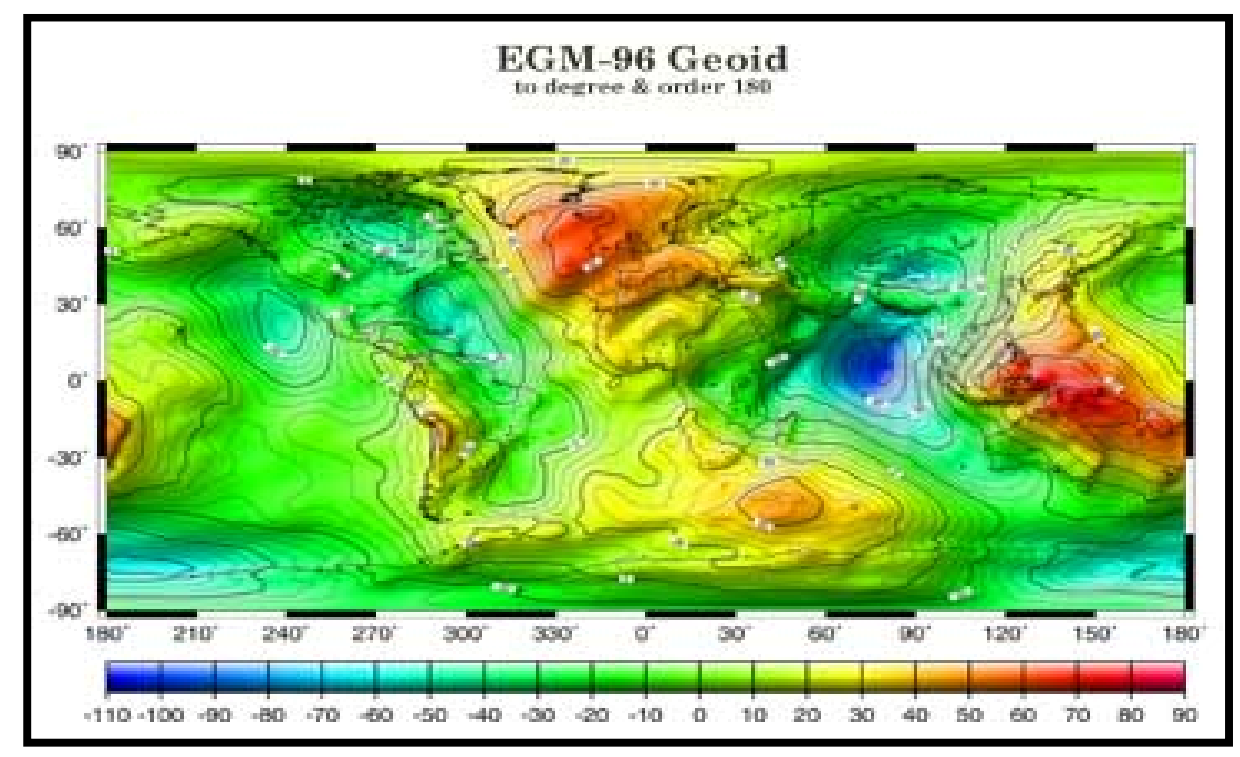

Figure (2): EGM96 global gravity model [8]

The WGS 84 constants used to define the geometry and the normal fields of the reference ellipsoid in the calculation of this geoid height file are the following [11]:

- $\mathrm{a}=6378137.0 \mathrm{~m}$ (semi-major axis of WGS 84 Ellipsoid)

- $\mathrm{f}=1.0 / 298.2572235630$ (flattening of WGS 84 Ellipsoid)

- $\mathrm{GM}=0.3986004418 \mathrm{D} 15 \mathrm{~m} * * 3 / \mathrm{s} * * 2$ (Earth's Gravitational Constant w/ atmosphere)

- OMEGA=7292115.D-11 radians/sec (Earth's angular velocity)

\section{Bench Mark Parameters}

All GPS derived dataset obtained from this research was setting to the WGS84 reference ellipsoid in order to be coinciding with the EGM96 geoid model condition.

In the present study, equation (1) was applied to calculate the orthometric height of the basic benchmark $(\mathrm{H})$ by algebraically subtracting an interpolated geoid height, N, (obtained from EGM96 Geoid Model), from a GPS ellipsoidal height, h.

The basic benchmark was located at end of the concrete slab of the entrance to the basketball playing ground of the Mosul University [3] as shown in figure (3). The geoidal undulation was calculated by using EGM96 correction calculator [12]. The ellipsoid height was measured by 
using the available GPS receiver (GARMIN eTrex Vista Cx GPS unit) with an average accuracy of $(4 \mathrm{~m})$.

Table (1) listed the geographical characteristics of the adopted basic benchmark as measured by this study.

\begin{tabular}{|c|c|c|c|c|c|c|}
\hline \multicolumn{2}{|c|}{$\begin{array}{l}\text { Geographical } \\
\text { coordinate }\end{array}$} & \multicolumn{2}{|c|}{ UTM coordinate } & \multirow{2}{*}{$\begin{array}{c}\text { GPS } \\
\text { ellipsoidal } \\
\text { height } \\
\text { (m) } \\
\text { (h) } \\
\end{array}$} & \multirow{2}{*}{$\begin{array}{c}\text { Geoidal } \\
\text { undulation } \\
(\mathrm{N})\end{array}$} & \multirow{2}{*}{$\begin{array}{l}\text { Orthometric } \\
\text { height (m) } \\
\text { (H) }\end{array}$} \\
\hline Latitude & Longitude & Northing & Easting & & & \\
\hline $\begin{array}{c}36 \\
\text { degree } \\
22 \\
\text { minute } \\
43.7 \\
\text { second } \\
\end{array}$ & $\begin{array}{l}43 \text { degree } \\
08 \text { minute } \\
\text { 33.3second }\end{array}$ & 4027567 & 333391 & 228 & 15.662 & 212.338 \\
\hline
\end{tabular}

Table (1): geographical characteristics of the basic benchmark

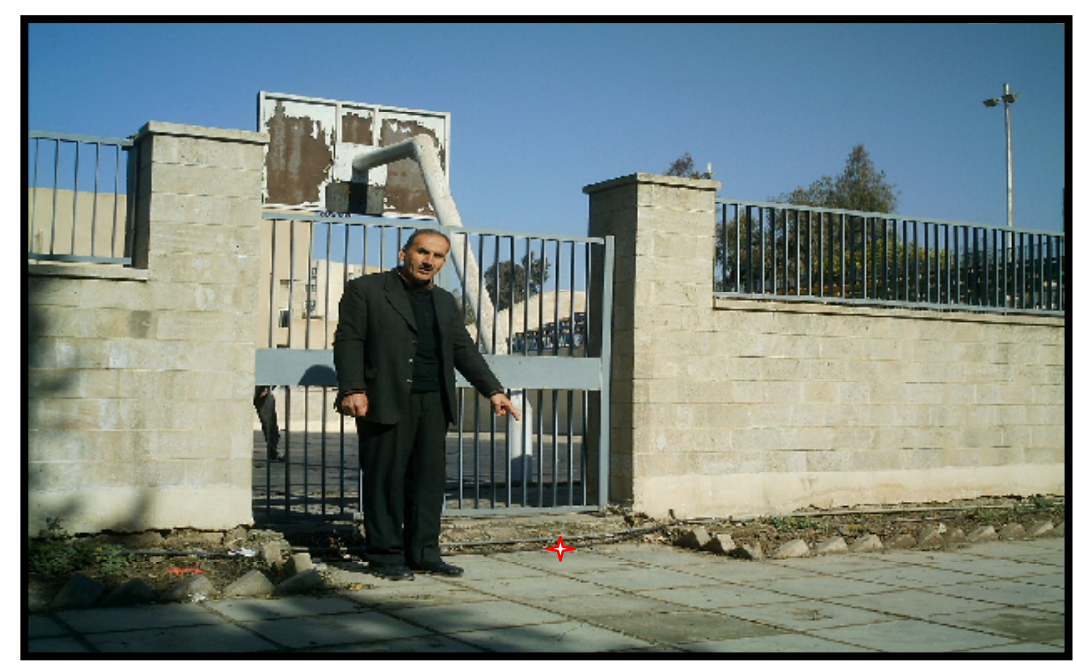


Figure (3): The location of the basic benchmark

\section{Leveling Derived Dataset}

In the present study, the leveling determination of the (15) points was related to the basic bench mark. The survey has been carried out by using conventional leveling instrument (Type: Wild(NAK2)) within accuracy of $(\mathrm{cm})$. The determination of the reduce level of these points were calculated by applied the height of differential leveling method[ref.13]. Figure (4) illustrates differential leveling method. In this method, a leveling instrument is positioned midway between a point at which the ground elevation is known (point A) and a point whose elevation is to be measured (B). The height of the instrument above the datum elevation is HI. The surveyor first reads a back sight measurement (BS) of a leveling stuff held by his trusty assistant over the benchmark at A. The height of the instrument can be calculated as the sum of the known elevation at the benchmark (ZA) and the back sight height (BS). The assistant then moves the stuff to point $B$, and then reads a foresight (FS) off the stuff at B. The elevation at B (ZB) can then be calculated as the difference between the height of the instrument (HI) and the foresight height (FS). 


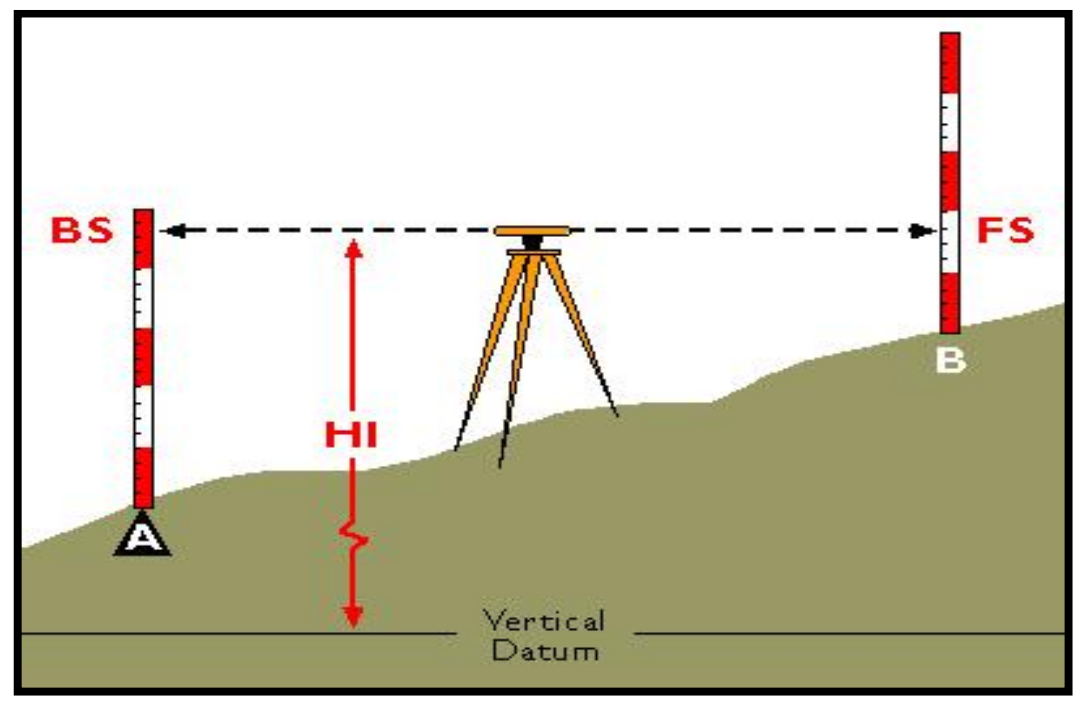

Figure (4): Differential leveling method

Therefore, the leveling calculations are obtained from [13]:

$\mathrm{HI}=$ elevation known $(\mathrm{ZA})+\mathrm{BS}$

Elevation new $(\mathrm{ZB})=\mathrm{HI}-\mathrm{FS}$

The resulting values of the leveling measurements carried out by this research for the (15) control points are shown in the Appendix (A).

Where:-

B.S. (Back Sight):- it is the first reading taken after the level is set-up and leveled.

F.S. (Fore Sight):- it is the last reading before the shifting of the instrument.

I.S. (intermediate Fore Sight):- it is referred to the all sights taken between the Back Sight and the Fore Sight.

H.I. (Height of Instrument):- it is the elevation or the reduced level of the plane collimation.

R.L. (Reduced Level):- it is referred to the elevation of any point with respect to the defined bench mark.

B.M. (bench mark):- it is a fixed point with defined elevation with respect to mean sea level. 
T.P. (Turing Point):- an exact, stable stuff position upon which both a foresight reading and then a back sight reading are observed.

\section{Results and Discussion}

Beside the above measurements by leveling instrument, the elevation of the selected points are also fixed by using the available GPS receiver. The purpose of the GPS measurements to determined the difference between the GPS-ellipsoidal height and the level (orthometric )height. Table (3) summarized the results of the GPS/Leveling measurements for the (15) controls points. The values of the leveling height (orthometric height) listed in the table (3) are measured with respect to the basic bench mark parameters shown in table (1). The value of the geoid undulation for the adopted basic bench mark is acceptable as compared with the globally range values $(-100$ to $+75 \mathrm{~m})$ as given by [15] with the WGS84 ellipsoid system. The height differences $(\Delta \mathrm{h})$ values shown in table (3) are range between $(9.352 \mathrm{~m})$ and $(16.086 \mathrm{~m})$, this factor is equivalent to the geoid separation $(\mathrm{N})$ explained in figure (1) and also acceptable with the above globally range values. The $(\Delta \mathrm{h})$ values can be used as a correction factor in the transformation process between the two elevation mode.

Table (2) indicates that the GPS derived heights are relatively greater than the level heights (orthometric heights), therefore the $(\mathrm{N})$ values given in $(+)$ sign. Generally, the geoid undulation $(\mathrm{N})$ relates to topographic relief as well as subsurface rock density variations.

The statistical information of the resulting Level and GPS derived height values are given in table (3).

A Geographic Information System uses geographically referenced data as well as non-spatial data and includes operations which support spatial analysis to provide information about the reference coordinate system for the GIS applications.

ArcGIS 9.1 software was applied in this study for the georeferencing process of the measured spatial data obtained from both GPS receiver and level instrument for the (15) control points) on the study map (IKONOS satellite image in MrSID format). 
Table (2): The data set of the GPS/Leveling observations

\begin{tabular}{|c|c|c|c|c|c|c|c|}
\hline \multirow{2}{*}{$\begin{array}{l}\text { Pt } \\
. n \\
\text { o. }\end{array}$} & \multicolumn{2}{|c|}{$\begin{array}{l}\text { Geographical } \\
\text { coordinates }\end{array}$} & \multicolumn{2}{|c|}{$\begin{array}{c}\text { UTM } \\
\text { coordinates }\end{array}$} & \multirow{2}{*}{$\begin{array}{c}\text { Leveli } \\
\text { ng } \\
\text { height } \\
\text { (m) }\end{array}$} & \multirow{2}{*}{$\begin{array}{c}\text { GPS } \\
\text { ellipsoid } \\
\text { al } \\
\text { height( } \\
\text { m) } \\
\end{array}$} & \multirow{2}{*}{$\begin{array}{r}\Delta_{h} \\
(\mathbf{m})\end{array}$} \\
\hline & Latitude & $\begin{array}{c}\text { Longitu } \\
\text { de }\end{array}$ & $\begin{array}{l}\text { Northi } \\
\text { ng }\end{array}$ & $\begin{array}{c}\text { Easti } \\
\text { ng }\end{array}$ & & & \\
\hline 1 & $\begin{array}{c}36: 22: 43 \\
.6\end{array}$ & $\begin{array}{c}43: 08: 4 \\
42\end{array}$ & $\begin{array}{c}40275 \\
59\end{array}$ & $\begin{array}{c}3336 \\
63\end{array}$ & $\begin{array}{c}218.13 \\
3\end{array}$ & 233 & $\begin{array}{c}14.8 \\
67\end{array}$ \\
\hline 2 & $\begin{array}{c}36: 22: 49 \\
.2\end{array}$ & $\begin{array}{l}43: 08: 3 \\
9.5\end{array}$ & $\begin{array}{c}40277 \\
33\end{array}$ & $\begin{array}{c}3335 \\
49\end{array}$ & $\begin{array}{c}216.84 \\
2\end{array}$ & 231 & $\begin{array}{c}14.1 \\
58\end{array}$ \\
\hline 3 & $\begin{array}{c}36: 22: 50 \\
.9\end{array}$ & $\begin{array}{c}43: 08: 4 \\
5.3\end{array}$ & $\begin{array}{c}40277 \\
83\end{array}$ & $\begin{array}{c}3336 \\
94\end{array}$ & $\begin{array}{c}217.23 \\
7\end{array}$ & 232 & $\begin{array}{c}14.7 \\
63\end{array}$ \\
\hline 4 & $\begin{array}{c}36: 22: 46 \\
.9\end{array}$ & $\begin{array}{c}\text { 43:08:4 } \\
9.5\end{array}$ & $\begin{array}{c}40276 \\
58\end{array}$ & $\begin{array}{c}3337 \\
97\end{array}$ & $\begin{array}{c}230.07 \\
4\end{array}$ & 244 & $\begin{array}{c}13.9 \\
26\end{array}$ \\
\hline 5 & $\begin{array}{c}36: 22: 45 \\
.7\end{array}$ & $\begin{array}{c}43: 08: 5 \\
0.5\end{array}$ & $\begin{array}{c}40276 \\
20\end{array}$ & $\begin{array}{c}3338 \\
21\end{array}$ & $\begin{array}{c}236.05 \\
7\end{array}$ & 250 & $\begin{array}{c}13.9 \\
43\end{array}$ \\
\hline 6 & $\begin{array}{c}36: 22: 53 \\
.5\end{array}$ & $\begin{array}{c}43: 08: 4 \\
8.9\end{array}$ & $\begin{array}{c}40278 \\
61\end{array}$ & $\begin{array}{c}3337 \\
86 \\
\end{array}$ & $\begin{array}{c}218.91 \\
4\end{array}$ & 235 & $\begin{array}{c}16.0 \\
86\end{array}$ \\
\hline 7 & $\begin{array}{c}36: 22: 40 \\
.1\end{array}$ & $\begin{array}{c}43: 08: 4 \\
4.1\end{array}$ & $\begin{array}{c}40274 \\
51\end{array}$ & $\begin{array}{c}3336 \\
58\end{array}$ & $\begin{array}{c}213.09 \\
3\end{array}$ & 229 & $\begin{array}{c}15.9 \\
07\end{array}$ \\
\hline 8 & $\begin{array}{c}36: 22: 39 \\
.3\end{array}$ & $\begin{array}{c}43: 08: 4 \\
1.6\end{array}$ & $\begin{array}{c}40274 \\
27\end{array}$ & $\begin{array}{c}3335 \\
95\end{array}$ & $\begin{array}{c}211.66 \\
3\end{array}$ & 226 & $\begin{array}{c}14.3 \\
37\end{array}$ \\
\hline 9 & $\begin{array}{c}36: 22: 33 \\
.5\end{array}$ & $\begin{array}{c}43: 08: 4 \\
0.8\end{array}$ & $\begin{array}{c}40272 \\
49\end{array}$ & $\begin{array}{c}3335 \\
72\end{array}$ & $\begin{array}{c}209.62 \\
8\end{array}$ & 220 & $\begin{array}{c}10.3 \\
72 \\
\end{array}$ \\
\hline 10 & $\begin{array}{c}36: 22: 33 \\
.0\end{array}$ & $\begin{array}{c}43: 08: 3 \\
6.0\end{array}$ & $\begin{array}{c}40272 \\
36\end{array}$ & $\begin{array}{c}3334 \\
52\end{array}$ & $\begin{array}{c}208.94 \\
8\end{array}$ & 219 & $\begin{array}{c}10.0 \\
52\end{array}$ \\
\hline 11 & $\begin{array}{c}36: 22: 32 \\
.3\end{array}$ & $\begin{array}{c}43: 08: 4 \\
4.4\end{array}$ & $\begin{array}{c}40272 \\
10\end{array}$ & $\begin{array}{c}3336 \\
61\end{array}$ & $\begin{array}{c}209.64 \\
8\end{array}$ & 219 & $\begin{array}{c}9.35 \\
2\end{array}$ \\
\hline 12 & $\begin{array}{c}36: 22: 32 \\
.8\end{array}$ & $\begin{array}{c}43: 08: 4 \\
8.3\end{array}$ & $\begin{array}{c}40272 \\
24\end{array}$ & $\begin{array}{c}3337 \\
58\end{array}$ & $\begin{array}{c}210.44 \\
8\end{array}$ & 220 & $\begin{array}{c}9.55 \\
2\end{array}$ \\
\hline 13 & $\begin{array}{c}36: 22: 30 \\
.4\end{array}$ & $\begin{array}{c}43: 08: 5 \\
3.5 \\
\end{array}$ & $\begin{array}{c}40271 \\
47 \\
\end{array}$ & $\begin{array}{c}3338 \\
86\end{array}$ & $\begin{array}{c}210.98 \\
8\end{array}$ & 224 & $\begin{array}{c}13.0 \\
12\end{array}$ \\
\hline 14 & $\begin{array}{c}36: 22: 31 \\
.3\end{array}$ & $\begin{array}{c}43: 08: 5 \\
3.5\end{array}$ & $\begin{array}{c}40271 \\
75\end{array}$ & $\begin{array}{c}3338 \\
87\end{array}$ & $\begin{array}{c}211.40 \\
8\end{array}$ & 24 & $\begin{array}{c}12.5 \\
92\end{array}$ \\
\hline
\end{tabular}




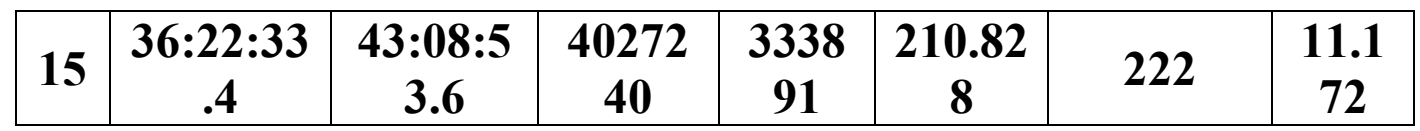

Table (3) Results of statistical analysis of GPS/Leveling height for the check points

\begin{tabular}{|c|c|c|}
\hline Statistic & $\begin{array}{c}\text { Leveling height } \\
\text { (orthometric height) }\end{array}$ & $\begin{array}{c}\text { GPS ellipsoidal } \\
\text { height }\end{array}$ \\
\hline Minimum & $\mathbf{2 0 8 . 9 4 8}$ & $\mathbf{2 1 9}$ \\
\hline Median & $\mathbf{2 1 2 . 3 3 8}$ & $\mathbf{2 2 8}$ \\
\hline Maximum & $\mathbf{2 3 6 . 0 5 7}$ & $\mathbf{2 5 0}$ \\
\hline Range & $\mathbf{2 7 . 1 0 9}$ & $\mathbf{3 1}$ \\
\hline Mean & $\mathbf{2 1 5 . 3 9 0}$ & $\mathbf{2 2 8 . 5}$ \\
\hline Standard Deviation & $\mathbf{7 . 4 3 6}$ & $\mathbf{8 . 6 5 3}$ \\
\hline
\end{tabular}

Figure (5) below shows the geographical location of the control points as well as the basic bench mark as distributed in the Mosul University Campus according to the WGS84-UTM coordinate system. Practically spatial coordinates based on local or global reference systems are usually converted to a map projection system for both spatial representations and map production. The most common projection used for spatial data to high accuracy is the Universal Transverse Mercator (UTM) projection, which is the usually adopted the required reference system and practically suited to maps of north south extent and also suitable for the remote sensing mapping. Figure (6) shown the 3D view of the study area with the control points as appear by using ArcScene/ArcGIS9.1 software.

Contour plot and the 3D surface mapping, showing the orthometric elevation (measured by level instrument) and the ellipsoidal elevation (measured by GPS receiver) is illustrated below in figure (7and 8, respectively). The interval between the contour lines for the leveling elevation shown in (figure 7) is equal to $(1 \mathrm{~m})$ while the interval in the GPS elevation shown in (figure 8 ) is equal to $(1.67 \mathrm{~m})$. As shown from the results that the GPS elevation readout have greater values for the contours 
interval than the contours interval of the leveling readout, this result can be related to the fact that the GPS elevation readout given in the absolute meters, while elevation readout in the leveling instrument was given in the decimal fraction. Also from the two figures ( 7 and 8 ), the concentration of the contour lines appear in the figures is referred to the high relief in the study area where it correspond to the elevation of $(236.057 \mathrm{~m})$ for the orthometric height and $(250 \mathrm{~m})$ for the GPS height. The orthometric heights so derived reflect local variations in topographic gradients.

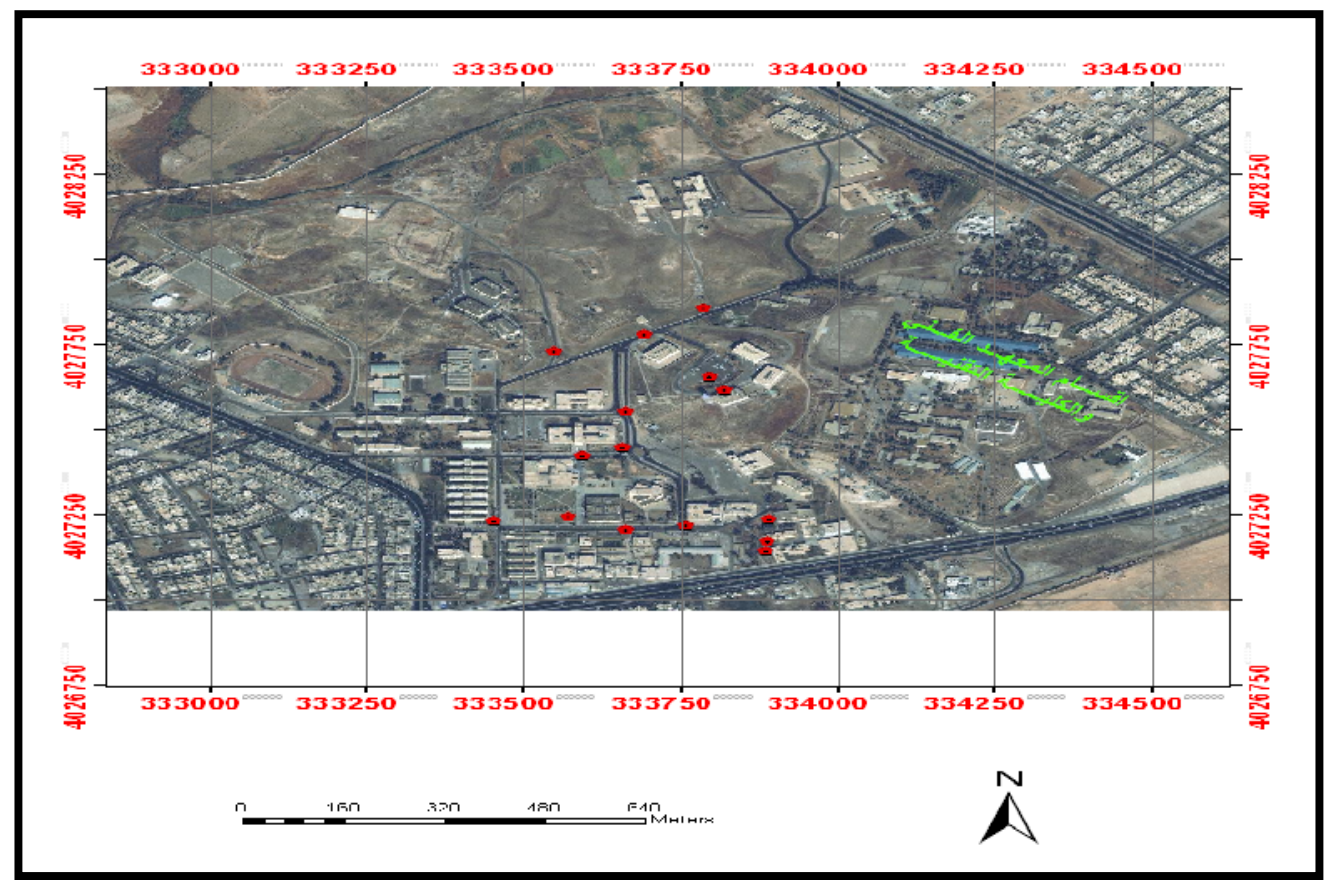

Figure (5): geographical location of (16) control points 


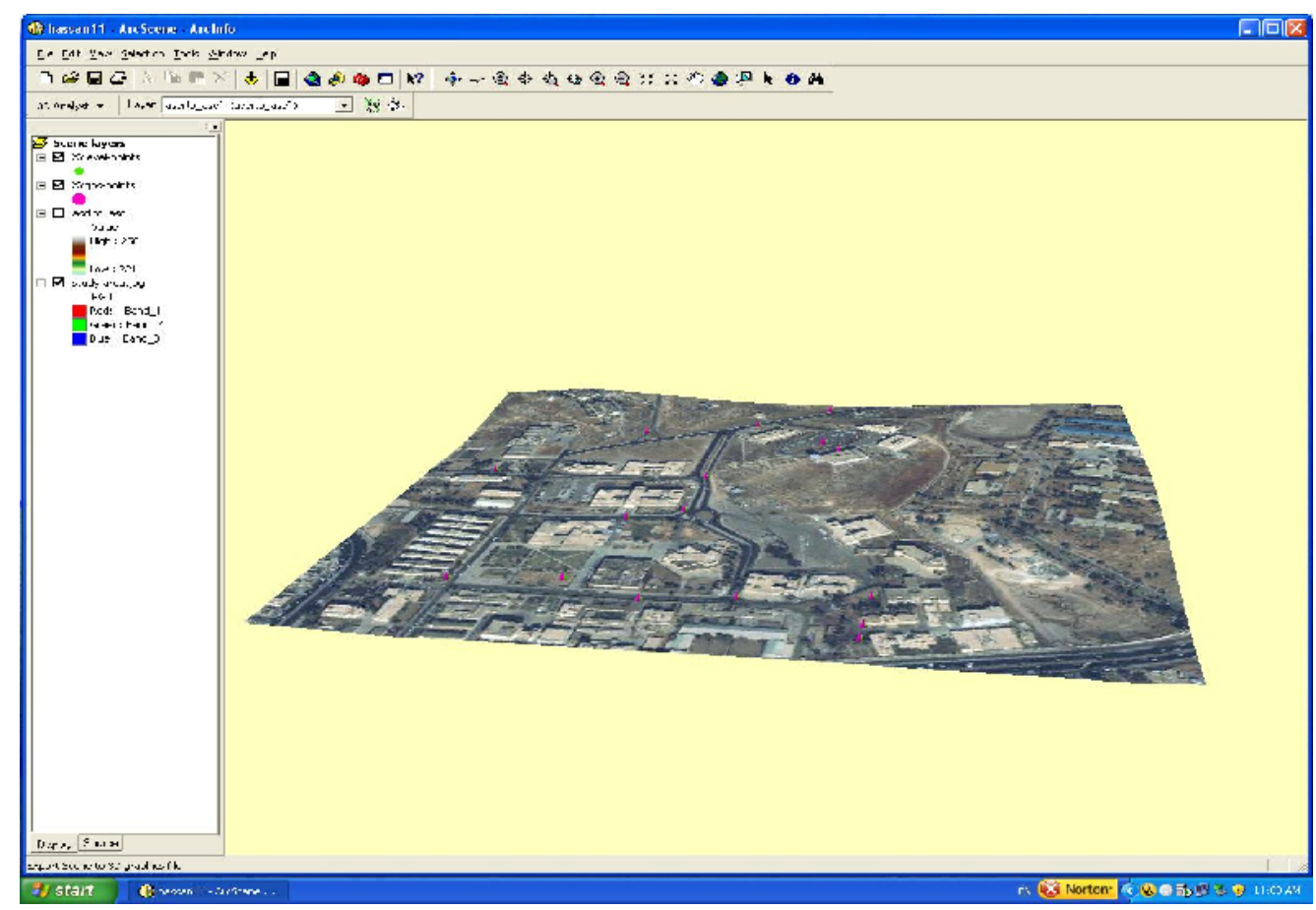


Figure (6): 3D view of the study area with control points

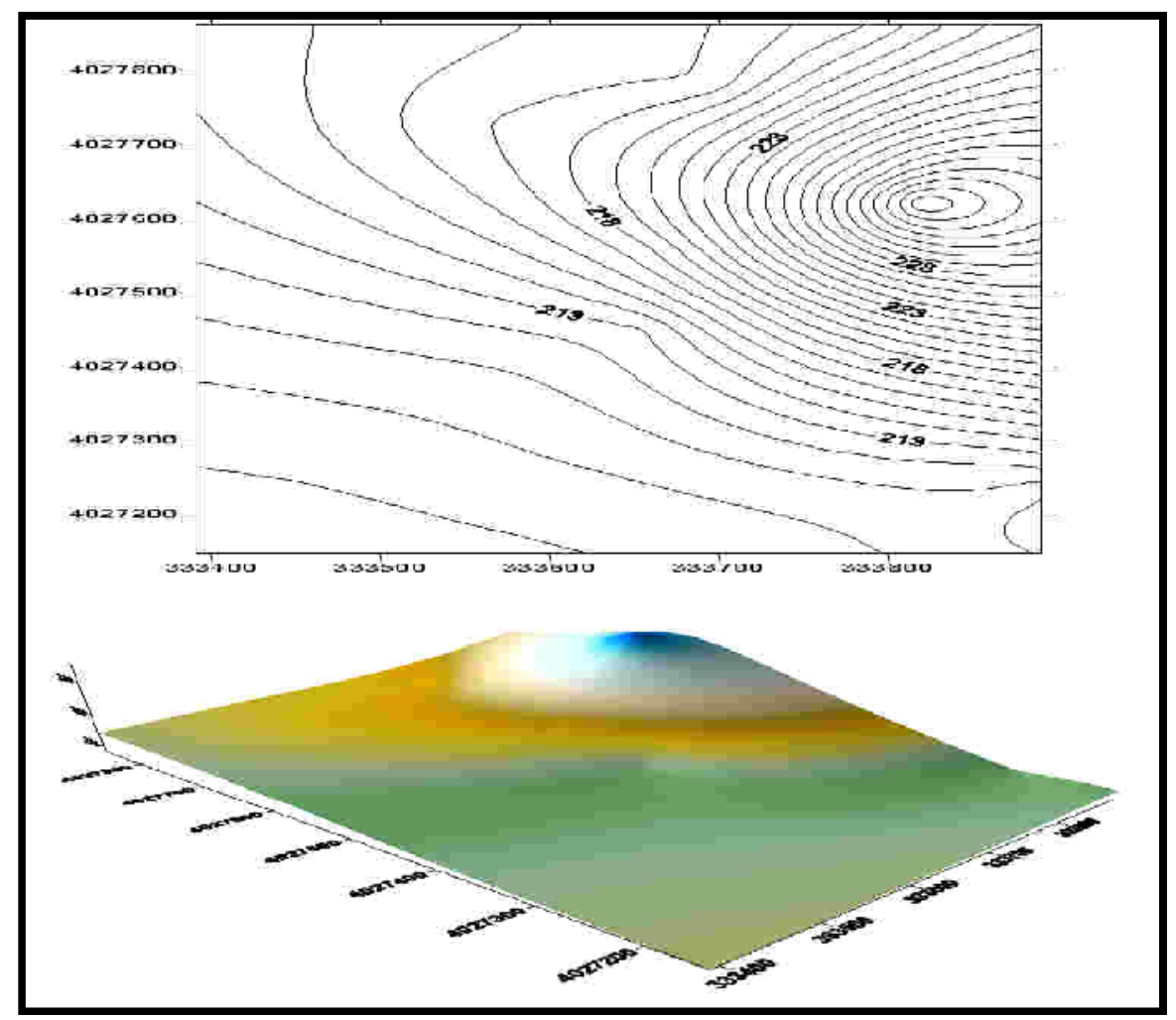

Figure (7): contour lines the 3D surface mapping for level elevation $(1 \mathrm{~m}$ intervals) 


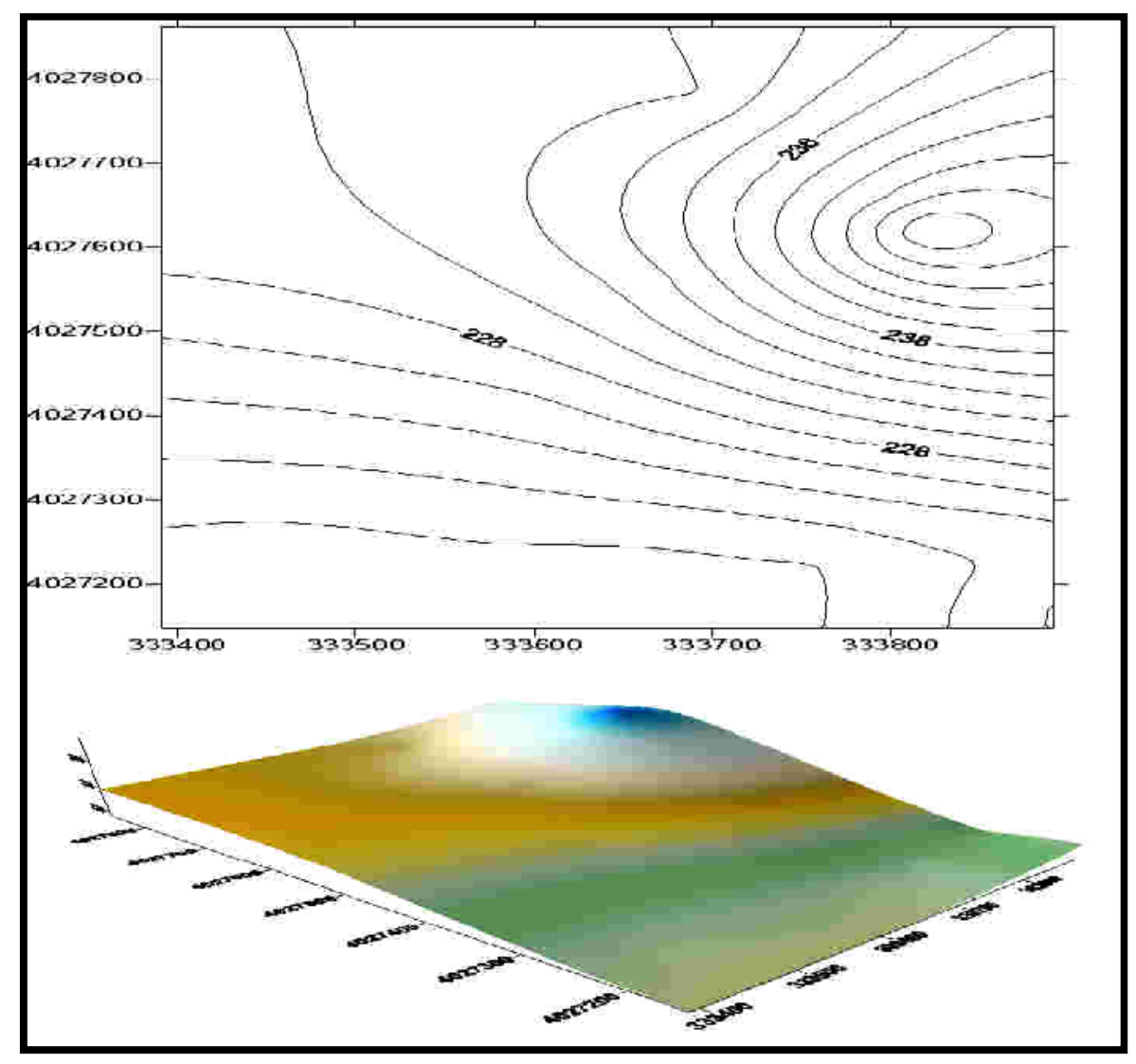

Figure (8): contour lines and the 3D surface mapping for GPS elevation ( $1.67 \mathrm{~m}$ intervals)

\section{Conclusions}

The study was taken up to realize the concept of deriving orthometric heights from GPS. The procedures and techniques adopted in this study is applied for basic bench mark and (15) control points distributed inside Mosul University Campus.

According to the results of this study, it is safely concluded that the applied procedures and techniques are successful to great extent and determining the orthometric height of any control point, on which GPS observation had been conducted, has become possible with certain level of accuracy, which is may be sufficient for the engineering and topographic surveys. However the role of an accurate gravimetric geoid becomes much more important when area under considerations is quite large and consisted of varying topography. 
GPS / leveling is especially useful for obtaining orthometric heights in areas which are either inaccessible by conventional methods or where Trans normal conditions disrupt the procedural requirements for leveling.

\section{References}

1. Kamal. A. A., 2006, "Unification of the Georeferencing Systems of GIS Spatial Data Infrastructure", Al-Ain Town Planning Department, available at: www.GISdevelopment.net, accessed at: 22/11/2006.

2. Al-Shaikh, Z. D. and Baker, H. A., 1973, "Gravity Survey of the Greater Mosul", Journal of the Geological Society of Iraq", vol.VI, pp.35-45.

3. Ahmad, T. Y., 1980, "Geophysical Investigation to the South and Southwest of Aski Kalak", M.Sc.Thesis, Mosul University.

4. Christopher, B., J., 1999,'"Geographical Information Systems and Computer Cartography", Addison Wesley Longman Limited, 318p.

5. Kiamehr, R., 2006, "Potential of the Iranian Geoid for GPS/Leveling ", Department of Surveying Engineering, University of Zanjan, available at: www.geomatics.kth.se/, accessed as: 22/12/2006, $10 \mathrm{p}$.

6. Algarni, D. A., 1997, "Geoid Modeling in Saudi Arabia", ITC Journal, vol.2, pp.114-120.

7. Weikko, A. H., and Helmut, M., 1967, "Physical Geodesy", W. H. FREEMAN AND COMPANY, LONDON, pp.47-50.

8. The NASA GSFC and NIMA Joint Geopotential Model, available at: http://cddisa.gsfc.nasa.gov/emg96/egm96.html, accessed at: 12/jan./2007.

9. Lemoine, F.G., Kunz, L., Pavlis, E.C., Kenyon, S.C., Rapp, R.H., Nerem, R.S., 1996, " The Development of the NASA GSFC and NIMA Joint Geopotential Model", International Symposium on Gravity, Geoid, and Marine Geodesy, (GRAGEOMAR 1996), The University of Tokyo, Tokyo, Japan, September 30-October 5, 1996, 10p.

10.Timar,G., Kis, K., Kenyeres, A., 2005, " Short-wavelength component of the geoid: a possible indicator of the isostatic character", Geophysical Research Abstracts, Vol. 7, 02636, 2p.

11. Kaplan, E. D., 1996, "Understanding GPS Principles and Applications", Artech House, Inc., 455p.

12. EGM96 correction calculator, 2007, available at: http://sps.unavco.org/geoid/

13. Bannister, A. and Raymond, S., 1977, "Surveying", Fourth Edition, Pitman Publishing Limited, 632p. 
14. Dennis, G. M. and Dru, A. S., 2007, "Converting GPS Height into NAVD88 Elevation with the GEOID96 Geoid Height Model ", National Geodetic Survey, NOAA, 10p.

Appendix (A)

Results of the leveling measurements for the (15) control points

\begin{tabular}{|c|c|c|c|c|c|}
\hline B.S & I.S & F.S & H.I & R.L & Remarks \\
\hline 3.73 & & & 216.068 & 212.338 & B.M. \\
\hline 3.912 & & 0.45 & 219.53 & 215.618 & T.P. \\
\hline 2.029 & & 1.397 & 220.162 & 218.133 & Point (1) \\
\hline \multirow[t]{2}{*}{0.765} & & 3.285 & 217.642 & 216.877 & T.P. \\
\hline & & 0.8 & & 216.842 & Point (2) \\
\hline B.S & I.S & F.S & H.I & R.L & Remarks \\
\hline \multirow[t]{2}{*}{4.07} & & & 220.947 & 216.877 & T.P. \\
\hline & & 3.71 & & 217.237 & Point (3) \\
\hline B.S & I.S & F.S & H.I & R.L & Remarks \\
\hline 4.07 & & & 220.947 & 216.877 & T.P. \\
\hline 5.025 & & 1.09 & 224.882 & 219.857 & T.P. \\
\hline 5.05 & & 0.705 & 229.227 & 224.177 & T.P. \\
\hline 2.27 & & 0.703 & 230.794 & 228.524 & T.P. \\
\hline 4.458 & & 0.72 & 234.532 & 230.074 & Point (4) \\
\hline \multirow[t]{2}{*}{3.61} & & 0.695 & 237.447 & 233.837 & T.P. \\
\hline & & 1.39 & $\mathbf{0}$ & 236.057 & Point (5) \\
\hline B.S & I.S & F.S & H.I & R.L & Remarks \\
\hline
\end{tabular}




\begin{tabular}{|c|c|c|c|c|c|}
\hline 2.425 & & & 219.662 & 217.237 & T.P. \\
\hline & & 0.748 & & 218.914 & Point (6) \\
\hline B.S & I.S & F.S & H.I & R.L & Remarks \\
\hline 0.41 & & & 218.543 & 218.133 & T.P. \\
\hline \multirow[t]{2}{*}{0.085} & & 4.425 & 214.203 & 214.118 & T.P. \\
\hline & & 1.11 & & 213.093 & Point (7) \\
\hline B.S & I.S & F.S & H.I & R.L & Remarks \\
\hline 0.41 & & & 218.543 & 218.133 & T.P. \\
\hline 0.085 & & 4.425 & 214.203 & 214.118 & T.P. \\
\hline \multirow[t]{2}{*}{0.69} & & 2.54 & 212.353 & 211.663 & Point (8) \\
\hline & & 2.725 & & 209.628 & Point (9) \\
\hline B.S & I.S & F.S & H.I & R.L & Remarks \\
\hline \multirow[t]{2}{*}{1.12} & & & 210.748 & 209.628 & T.P. \\
\hline & & 1.8 & & 208.948 & $\begin{array}{c}\text { Point } \\
\text { (10) }\end{array}$ \\
\hline B.S & I.S & F.S & H.I & R.L & Remarks \\
\hline \multirow[t]{2}{*}{1.12} & & & 210.748 & 209.628 & T.P. \\
\hline & & 1.1 & & 209.648 & $\begin{array}{c}\text { Point } \\
\text { (11) }\end{array}$ \\
\hline B.S & I.S & F.S & H.I & R.L & Remarks \\
\hline 1.12 & & & 210.748 & 209.628 & T.P. \\
\hline \multirow[t]{2}{*}{1.86} & & 0.3 & 212.308 & 210.448 & $\begin{array}{c}\text { Point } \\
\text { (12) }\end{array}$ \\
\hline & & 1.32 & & 210.988 & $\begin{array}{c}\text { Point } \\
\text { (13) }\end{array}$ \\
\hline
\end{tabular}




\begin{tabular}{|c|c|c|c|c|c|} 
B.S & I.S & F.S & H.I & R.L & Remarks \\
\hline 1.12 & & & 210.748 & 209.628 & T.P. \\
\hline 1.86 & & 0.3 & 212.308 & 210.448 & T.P. \\
\hline & & 0.9 & & 211.408 & $\begin{array}{c}\text { Point } \\
(14)\end{array}$ \\
\hline B.S & I.S & F.S & H.I & R.L & Remarks \\
\hline 1.12 & & & 210.748 & 209.628 & T.P. \\
\hline 1.86 & & 0.3 & 212.308 & 210.448 & T.P. \\
\hline & & 1.48 & & 210.828 & \begin{tabular}{c} 
Point \\
\hline
\end{tabular} \\
& & $15)$ &
\end{tabular}

